\title{
Prevalence of anticardiolipin antibodies in juvenile chronic arthritis
}

\author{
R Caporali, A Ravelli, F De Gennaro, G Neirotti, C Montecucco, A Martini
}

\begin{abstract}
The prevalence of anticardiolipin antibodies was evaluated in 70 children with juvenile chronic arthritis (JCA), in 25 adult patients with rheumatoid arthritis, in 42 healthy children and in $\mathbf{4 0}$ adult controls. Thirty seven (53\%) patients with JCA were positive for IgG or IgM anticardiolipin antibodies, or both, and 30 (43\%) for IgG anticardiolipin antibodies. In contrast, only seven (28\%) adult patients with iheumatoid arthritis presented anticardiolipin antibodies, which were of IgG class in four (16\%) cases. IgG anticardiolipin antibodies were negative in all control subjects while IgM anticardiolipin antibodies were detected in two (5\%) children and in four $(\mathbf{1 0} \%)$ adult controls. No correlations were found in patients with JCA between the presence or titres of anticardiolipin antibodies and various clinical or laboratory variables. No patient with anticardiolipin antibodies showed any feature of the anticardiolipin syndrome.
\end{abstract}

Juvenile chronic arthritis (JCA) is an heterogeneous condition, which is currently divided into different subtypes according to symptoms at onset. ${ }^{12}$ Among numerous immunological abnormalities seen in JCA only antinuclear antibodies and IgM rheumatoid factor are currently thought to be useful in patient classification and management. ${ }^{2} 3$ Some autoantibodies with defined specificity, such as antihistone $^{45}$ and anticollagen antibodies, ${ }^{67}$ have also been detected in patients with JCA, but their significance is still poorly understood.

Anticardiolipin antibodies are antiphospholipid antibodies, which can be found in patients with systemic lupus erythematosus and other autoimmune syndromes. ${ }^{8}$ Their presence has been correlated with various clinical manifestations, including thromboembolic phenomena, autoimmune cytopenia, and neurological disease. $^{8-10}$

In this study we tested 70 patients with JCA for the presence of anticardiolipin antibodies.

\section{Patients and methods}

PATIENTS

Seventy children ( 26 boys, 44 girls), ranging in age from 1 year and 5 months to 17 years and 11 months (mean age 8.3 years), whose parents gave permission for drawing extra blood at the time of routine venepuncture, were studied. All fulfilled the criteria for diagnosis of $\mathrm{JCA}^{1}$ and had been categorised by onset type according to the criteria of the juvenile rheumatoid arthritis criteria subcommittee of the American Rheumatism Association (ARA). ${ }^{1}$ The mean disease duration was 3.5 years. Thirty patients presented a systemic form, eight a polyarticular, and 32 a pauciarticular form. To reduce the heterogeneity of our group patients who were positive for HLA-B27 or rheumatoid factor were excluded from the study. Patients were divided according to disease activity into those with active disease and those in remission, as previously described. ${ }^{11}$ At the time of the study 53 patients had active disease and 17 were in remission. Thirteen patients were receiving no treatment, 42 were taking non-steroidal anti-inflammatory drugs (NSAIDs), four were receiving oral slow acting antirheumatic drugs and NSAIDs, and 11 were receiving low dose steroids in combination with NSAIDs on alternate days.

Forty two normal healthy children within the same age range, whose parents gave permission for drawing extra blood at the time of routine examinations, served as controls.

In addition, 25 adult patients ( 20 female, five male) with rheumatoid arthritis classified according to the ARA revised criteria, ${ }^{12}$ ranging in age from 28 to 74 years (mean age 45.3 years), and $\mathbf{4 0}$ adult healthy volunteers matched for age and sex were evaluated for the presence of anticardiolipin antibodies.

\section{METHODS}

Serum anticardiolipin antibodies were detected by an immunosorbent assay by the method of Gharavi et $a^{13}$ with slight modifications. ${ }^{14}$ Briefly, serum samples were diluted $1 / 50$ in $10 \%$ fetal calf serum in phosphate buffered saline, pH 7.4 (PBS-FCS), and incubated in triplicate for three hours in polyvinyl microtitre plates previously coated with $25 \mathrm{ml}$ of $50 \mathrm{mg} / \mathrm{ml}$ cardiolipin in ethanol (Sigma Chemical, St Louis, Missouri, United States), washed in PBS, and blocked with PBS-FCS for one hour. After three additional washings the plates were incubated with a peroxidase conjugated rabbit antiserum selectively directed to human IgG, IgM, or IgA (Dakopatts, Denmark) at $1 / 1000$ dilution in PBS-FCS. After three washings 100 $\mathrm{ml}$ of $2 \mathrm{mg} / \mathrm{ml} o$-phenylenediamine (Sigma) in $0.1 \mathrm{M}$ phosphate buffer pH 6 plus $30 \% \mathrm{H}_{2} \mathrm{O}_{2}$ was added to each well. The reaction was stopped by adding $2 \mathrm{M} \mathrm{H}_{2} \mathrm{SO}_{4}$, and the optical density was read at $492 \mathrm{~nm}$ with a Titertek multiscan reader (Flow Laboratories). Upper normal limits for IgG, IgM, or IgA antibodies were set as the mean normal values plus five standard deviations of normal control samples. 
Prevalence of anticardiolipin antibodies in patients with juvenile chronic arthritis and rheumatoid arthritis and in healthy subjects

\begin{tabular}{|c|c|c|c|c|}
\hline & \multirow{2}{*}{$\begin{array}{l}\text { Subjects } \\
\text { tested } \\
(n)\end{array}$} & \multicolumn{3}{|c|}{ No (\%) subjects positive for anticardiolipin antibodies } \\
\hline & & $\begin{array}{l}\text { IgG } G \\
(\text { only })\end{array}$ & $\begin{array}{l}\text { IgM } \\
\text { (only) }\end{array}$ & $\begin{array}{l}\operatorname{Ig} G \\
\text { and } I g M\end{array}$ \\
\hline $\begin{array}{l}\text { Juvenile chronic arthritis } \\
\text { Rheumatoid arthtiris } \\
\text { Controls-children } \\
\text { Controls-adults }\end{array}$ & $\begin{array}{l}70 \\
25 \\
42 \\
40\end{array}$ & $\begin{array}{l}17(24) \\
4(16) \\
0 \\
0\end{array}$ & $\begin{array}{l}7(10) \\
3(12) \\
2(5) \\
4(10)\end{array}$ & $\begin{array}{l}13(19) \\
0 \\
0 \\
0\end{array}$ \\
\hline
\end{tabular}

IgG and IgM antibody titre was expressed as arbitrary units using reference standard serum samples ${ }^{15}$ : serum samples with IgG values ranging from 8 to 15 arb units or IgM from 5 to 15 arb units were defined as low positive, while values above 15 arb units were considered as high positive. No standard reference serum samples were available for titration of IgA anticardiolipin antibodies.

Statistical analysis was by Wilcoxon's test for comparison of differences between means and by linear regression analysis for calculation of correlation coefficients.

\section{Results}

The table and figure show the results of IgG and IgM anticardiolipin antibody determinations in patients with JCA, in adults with rheumatoid arthritis, and in healthy controls.

Of the 70 patients with JCA tested, 37 (53\%)

a

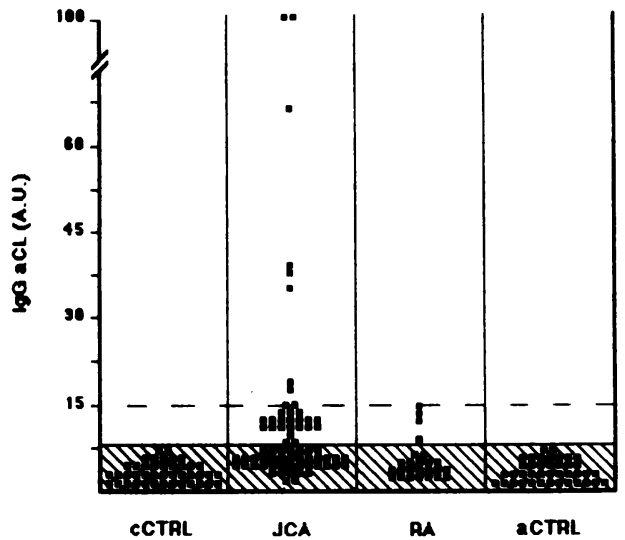

b

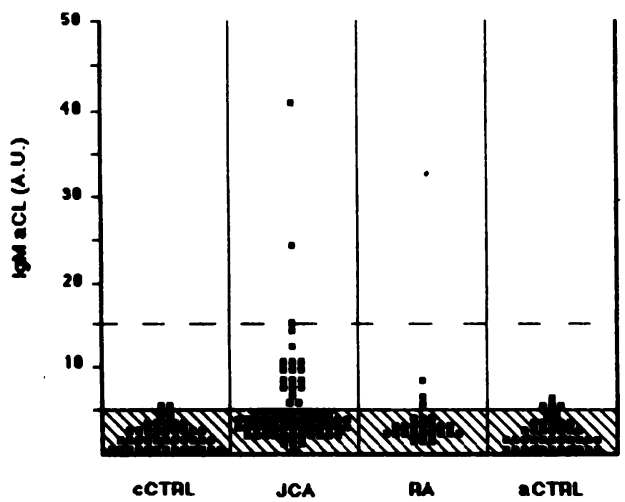

(a) IgG and (b) IgM anticardiolipin antibody levels in patients with juvenile chronic arthritis (FCA), rheumatoid arthritis $(R A)$ and in normal children (CCTRL) and adults (aCTRL). The values above the dashed line are considered as high positive, those between the dashed and the continuous line as low positive, and those below the continuous line as negative. $A . U .=$ arbitrary $u$ mits. were positive for IgG or IgM anticardiolipin antibodies, or both, and $30(43 \%)$ for IgG anticardiolipin antibodies. In contrast, only seven out of $25(28 \%)$ adult patients with rheumatoid arthritis presented anticardiolipin antibodies, which were of IgG class in four cases (16\%). IgG anticardiolipin antibodies were negative in all control subjects while IgM anticardiolipin antibodies were present in two children $(5 \%)$ and in four adult controls $(10 \%)$.

Of the 30 patients with JCA positive for IgG anticardiolipin antibodies, eight $(27 \%)$ were in the high positive group and $22(73 \%)$ in the low positive group. All adult patients with rheumatoid arthritis were in the low positive group.

No significant correlations were found in patients with JCA between anticardiolipin antibody titres and clinical subtypes, disease activity defined on clinical grounds, onset age, disease duration, presence of iridocyclitis or other extra-articular manifestations, erythrocyte sedimentation rate, antinuclear antibody positivity, partial thromboplastin time, outcome, and treatment. All patients with a high titre of IgG anticardiolipin antibodies had a raised erythrocyte sedimentation rate. No patient presented with acute occlusive vascular episodes or cytopenia.

\section{Discussion}

Our results show a high prevalence $(53 \%)$ of anticardiolipin antibodies in patients with JCA. IgG anticardiolipin antibodies were present in $43 \%$ of patients with JCA and a quarter of these positive cases presented high antibody titres. The prevalence and the titre of IgG anticardiolipin antibodies in patients with JCA were also markedly higher than those found in a group of adult patients with rheumatoid arthritis. This finding may be regarded as a further distinctive feature between JCA and adult onset rheumatoid arthritis.

Previous studies on anticardiolipin antibodies in childhood have focused primarily on systemic lupus erythematosus and related autoimmune conditions. ${ }^{16-18}$ In a study of patients with JCA Leak found a low titre of anticardiolipin antibodies in $29 \%$ of patients with antinuclear antibodies in association with active arthritis and a poor outcome. ${ }^{19}$ Moreover, recently, Shergy et al reported IgG anticardiolipin antibodies in five of 12 patients with JCA; four of these patients had also a positive antinuclear antibody test. ${ }^{16}$

Our study was carried out on a larger series of patients with JCA and did not show any association between anticardiolipin antibodies and antinuclear antibodies or between anticardiolipin antibodies and any other clinical or laboratory feature. Indeed, the prevalence of anticardiolipin antibodies in our antinuclear antibody positive patients was $50 \%$ and was similar to that found in patients with a negative antinuclear antibody test. A lack of correlation between a positive antinuclear antibody test and anticardiolipin antibodies has been found also in other autoimmune disorders. ${ }^{20} 21$

It should be noted that all patients with high titre IgG anticardiolipin antibodies had a raised 
erythrocyte sedimentation rate. This finding might suggest that these antibodies are present in high titre only in patients with active disease; no correlation was found between anticardiolipin antibodies and erythrocyte sedimentation rate or disease activity defined on clinical grounds, however.

The presence of anticardiolipin antibodies is often associated with circulating anticoagulant activity and with distinctive clinical features, including deep vein and arterial thromboses, autoimmune cytopenia, cutaneous necroses, and neurological disease; this clinical picture is currently defined as 'anticardiolipin syndrome'.10 This syndrome has been reported more often in patients with IgG anticardiolipin antibodies and high antibody titres ${ }^{13} 22$ and has been found also in children. ${ }^{17}{ }^{18}$ We found no association between anticardiolipin antibodies and either abnormal clotting tests or specific clinical features in our patients with JCA, however, despite a large number of cases with high titre IgG anticardiolipin antibodies. This is in accordance with the general view that the clinical and biological significance of these antibodies may be different in different conditions. 923

In conclusion, our study showed a high prevalence of anticardiolipin antibodies in JCA. The prevalence and the titre of anticardiolipin antibodies in patients with JCA were much higher than those found in adult rheumatoid arthritis. No correlations were found between anticardiolipin antibodies and specific clinical and laboratory features. Further studies are needed to clarify the significance of these antibodies in JCA and their possible usefulness in further defining the heterogeneity of this condition.

This work is partially supported by IRCCS S Matteo, Pavia and CNR (89.02675.04), Rome, Italy.

1 Brewer E J, Bass J, Baum J, et al. Current proposed revision of the JRA criteria. Arthritis Rhewem 1977; 20: 195-9.

2 Ansell B M. Rhewematic disorders in childhood. London: Butterworth, 1980.
3 Martini A. Immunological abnormalities in juvenile chronic arthritis. Scand F Rherumatol Suppl 1987; 66: 107-18.

4 Pauls J D, Silverman E, Laxer R M, Fritzler M J. Antibodies to histones $\mathrm{Hl}$ and $\mathrm{H} 5$ in sera of patients with juvenile rheumatoid arthritis. Arthritis Rheum 1989; 32: 877-83.

5 Malleson P, Petty R E, Fung M, Candido E P M. Reactivity of antinuclear antibodies with histones and other antigens in juvenile rheumatoid arthritis. Arthritis Rheum 1989; 32:

6 Haynes D C, Gershwin M E, Robbins D L, Miller III J J, Cosca D. Autoantibody profiles in juvenile arthritis. I Rheumatol 1986; 13: 358-63.

7 Rowley M J, Gershwin M E, Mackay I R. Collagen antibodies in juvenile arthritis and adult rheumatoid arthritis: differences in levels and type-specificity. I R herematol 1988; 15: ences in

8 Harris E N, Gharavi A E, Hughes G R V. Antiphospholipid antibodies. Clin Rhewem Dis 1985; 11: 591-609.

9 Montecucco C, Longhi M, Caporali R, De Gennaro F. Haematological abnormalities associated with anticardiolipin antibodies. Haematologica (Pavia) 1989; 74: 195-204.

10 Hughes G R V, Harris E N, Gharavi A E. The anticardiolipin syndrome. I Rherumatol 1986; 13: 486-9.

11 Martini A, Ravelli A, Notarangelo L D, et al. Enhanced interleukin 1 and depressed interleukin 2 production in juvenile arthritis. I Rheumatol 1986; 13: 598-603.

12 Arnett F C, Edworthy S M, Bloch D A, et al. The American Rheumatism Association 1987 revised criteria for the classification of theumatoid arthritis. Arthritis Rherem 1988; 31: 315-24.

13 Gharavi A E, Harris E N, Asherson R A, Hughes G R V. Anticardiolipin antibodies: isotype, distribution, and phospholipid specificity. Ann Rheum Dis 1987; 46: $1-9$.

14 Montecucco C, Di Lauro M, Bobbio-Pallavicini E, et al. Antiphospholipid antibodies and thrombotic thrombocytopenic purpura. Clin Exp Rhewmatol 1987; 5: 355-8.

15 Harris E N, Gharavi A E, Tincani A, et al. Affinity purified anticardiolipin and anti-DNA antibodies. 7 Clin Lab Immunol 1985; 17: 155-62.

16 Shergy W J, Kredich D W, Pisetsky D S. The relationship of anticardiolipin antibodies to disease manifestations in pediatric systemic lupus erythematosus. $\mathcal{f}$ Rherematol 1988 ; pediatric syst $1389-94$.

17 Pelkonen P, Simell O, Rasi V, Vaarala O. Venous thrombosis associated with lupus anticoagulant and anticardiolipin antibodies. Acta Paediatr Scand 1988; 77: 767-72.

18 Ravelli A, Caporali R, Bianchi E, et al. Anticardiolipin syndrome in childhood: a report of two cases. Clin Exp Rherematol 1990; 8: 95-8.

19 Leak A M. Autoantibody profile in juvenile chronic arthritis. Ann Rhewen Dis 1988; 47: 178-82.

20 Caporali R, Longhi M, De Gennaro F, Di Lauro M Carnevale R, Montecucco C. Antiphospholipid antibodyassociated thrombocytopenia in autoimmune diseases. Medical Science Research 1988; 16: 537-9.

21 Meyer O, Piette J C, Bourgenois P, et al. Antiphospholipid antibodies: a disease marker in 25 patients with antinuclear antibodies: a disease marker in 25 patients with antinuclear
antibody negative systemic lupus erythematosus (SLE). antibody negative systemic lupus erythematosus (SLE). Comparison with a group of 91 patients with antinucl
antibody positive SLE. I Rheumatol 1987; 14: 502-6.

22 Harris E N, Chan J K, Asherson R A, Aber V R, Gharavi A E, Hughes G R V. Thrombosis, recurrent fetal loss and thrombocytopenia. Predictive value of the anticardiolipin antibody test. Arch Intern Med 1986; 146: 2153-6.

23 Harris N E, Hughes G R V. Antiphospholipid antibodies. In: McCarthy D J, ed. Arthritis and allied conditions. Philadelphia, Lea and Febiger, 1989: 1068-79. 